\title{
The diagnostic accuracy of dopamine transporter SPECT imaging to detect nigrostriatal cell loss in patients with Parkinson's disease or clinically uncertain parkinsonism: a systematic review
}

\author{
Sven R Suwijn ${ }^{1 *}$, Caroline JM van Boheemen ${ }^{2}$, Rob J de Haan ${ }^{3}$, Gerrit Tissingh ${ }^{4}$, Jan Booij ${ }^{5}$ and Rob MA de Bie ${ }^{1}$
}

\begin{abstract}
In specialized movement disorder centers, Parkinson's disease (PD) is wrongly diagnosed in 6 to $25 \%$ of cases. To improve the accuracy of the clinical diagnosis, it is necessary to have a reliable and practical reference standard. Dopamine transporter single-photon emission computed tomography (DAT SPECT) imaging might have the potential (high diagnostic accuracy and practical to use) to act as reference standard in detecting nigrostriatal cell loss in patients with (early stage) parkinsonism. We performed a systematic review to evaluate if DAT SPECT imaging can be used as such. Relevant studies were searched in the MEDLINE and EMBASE databases. Studies were selected when they met the following criteria: (1) all patients were adults with a clinical diagnosis of PD or clinically uncertain parkinsonism and (2) the study reported original data. In addition, studies needed to fulfill one of the two following criteria: (1) patients underwent at least one DAT SPECT and had a neuropathological confirmed diagnosis and (2) patients underwent at least two DAT SPECT scans, performed at least 2 years apart. The search identified 1,649 articles. Eight studies fulfilled our selection criteria and were included in this review. There was only one study including patients with diagnostic uncertainty. Sensitivity and specificity of DAT SPECT imaging to detect nigrostriatal cell loss were $98 \%$. The other studies included patients with a diagnosis of PD in whom there was no uncertainty. In these studies, sensitivity was 100\%. Our systematic review indicates that DAT SPECT imaging seems to be accurate to detect nigrostriatal cell loss in patients with parkinsonism.
\end{abstract}

Keywords: Diagnostic accuracy; Clinical diagnosis; Parkinson's disease; Parkinsonism; Dopamine transporter; Single-photon emission computed tomography; Nigrostriatal cell loss

\section{Review}

\section{Introduction}

Parkinsonism is a clinical syndrome characterized by bradykinesia and at least one of the following symptoms: rest tremor, muscular rigidity, and postural instability. Parkinsonism is most commonly caused by idiopathic Parkinson's disease (PD) [1,2]. However, parkinsonism is also a prominent feature in, for example, progressive supranuclear palsy (PSP), multiple system atrophy (MSA), psychogenic parkinsonism, dementia with Lewy bodies

\footnotetext{
* Correspondence: s.r.suwijn@amc.uva.nl

'Department of Neurology, Academic Medical Center, University of Amsterdam, Meibergdreef 9, PO Box 22660, 1100 DD Amsterdam, The Netherlands

Full list of author information is available at the end of the article
}

(DLB), vascular parkinsonism, and drug-induced parkinsonism. There is no definite test to confirm the cause of parkinsonism in clinical practice, except for the vascular causes of parkinsonism. Therefore, diagnostic criteria have been developed in the past 20 years [3-6]. Although the diagnosis is straightforward when patients have a classic presentation, establishing the cause of parkinsonism can be challenging, especially in early stages $[7,8]$. In specialized movement disorder centers, PD is wrongly diagnosed in 6 to $25 \%$ of cases [4,9-11]. General neurologists may even make a misdiagnosis up to $35 \%$ [7]. In a communitybased study in Wales, only $53 \%$ of patients, treated with antiparkinson medication in primary care, met the Queen Square Brain Bank criteria for the clinical diagnosis of PD 
when reexamined by an experienced movement disorder specialist [12].

The different causes of parkinsonism can be classified into two distinct groups; diseases with nigrostriatal cell loss (e.g., PD, MSA, PSP, and DLB) and diseases without nigrostriatal cell loss (e.g., psychogenic parkinsonism, dystonic tremor, dopa-responsive dystonia, and druginduced parkinsonism). This classification is of clinical importance since the prognosis is considerably worse in parkinsonism characterized by loss of nigrostriatal cells [13]. Patients without nigrostriatal cell loss, except for dopa-responsive dystonia, do not benefit from treatment with dopaminomimetics and require different treatment $[5,13,14]$.

The current reference standard (or gold standard) of parkinsonism is pathological evaluation. Although accurate, it is not a practical standard for the validation of new diagnostic tools because the time between diagnosis and death is often decades. Therefore, there is a need for an alternative in vivo reference standard to detect nigrostriatal dopaminergic cell loss in patients with parkinsonism.

Several different diagnostic tools have been evaluated in their ability to detect nigrostriatal cell loss. The most widely used tests are dopamine transporter singlephoton emission computed tomography (DAT SPECT), $\left[{ }^{18} \mathrm{~F}\right]$ DOPA positron emission tomography (PET), and transcranial sonography (TCS).

\section{Tests used in establishing the cause of Parkinsonism}

PET is a radiotracer-based method that can assess the in vivo function of the dopaminergic and other neurotransmitter systems. $\left[{ }^{18} \mathrm{~F}\right] \mathrm{DOPA}$ PET is a reliable tool to establish nigrostriatal cell loss but not very practical in clinical practice because the technique is only available in a limited number of centers, is expensive, and expertise in cerebral PET imaging is essential $[15,16]$.

DAT SPECT imaging - a practical, less expensive, and more widely available technique than $\left[{ }^{18} \mathrm{~F}\right] \mathrm{DOPA}$ PET has been incorporated in most centers as diagnostic tool $[17,18]$. DAT tracers like $\left[{ }^{123} \mathrm{I}\right] \mathrm{FP}-\mathrm{CIT}$ are typically used. Recent studies have shown that DAT SPECT imaging might be a sensitive method to establish nigrostriatal dopaminergic degeneration [19-24]. For example, people with subclinical and even preclinical PD already have clear deficits of the nigrostriatal pathway [21,25-28]. Also, if the scan does not show a nigrostriatal deficit, it is highly unlikely that the patient suffers from symptoms caused by nigrostriatal cell loss $[11,29,30]$. SPECT with tracers labeling postsynaptic dopamine $\mathrm{D}_{2 / 3}$ receptors (e.g., $\left[{ }^{123} \mathrm{I}\right]$ Iodobenzamide or $\left[{ }^{123} \mathrm{I}\right]$ Iodobenzofuran) shows a relatively low diagnostic accuracy, 59 to $80 \%$ sensitivity and 46 to $50 \%$ specificity in differentiating PD from nonneurodegenerative diseases [31].
Hyperechogenicity in the area of the midbrain has been consistently found in 79 to $90 \%$ of patients with PD using TCS [27,32-36]. However, in 6 to $12 \%$ of healthy volunteers, hyperechogenicity of the substantia nigra is also found [33,36,37]. This is even higher (16\%) in patients with essential tremor [38].

To summarize, DAT SPECT imaging appears to be the most suitable candidate to act as reference standard in detecting nigrostriatal cell loss in patients with (early stage) parkinsonism. Therefore, we performed a systematic review to assess the diagnostic accuracy of DAT SPECT imaging.

\section{Methods}

\section{Literature search}

We searched the electronic databases MEDLINE and EMBASE using the entire time scale up to July 2013. Both search strategies are included in Additional file 1. Furthermore, we searched the reference lists of all relevant articles to identify additional published studies for possible inclusion in the review. We did not impose any language restrictions.

\section{Selection of studies}

The list of titles and abstracts was screened by two independent reviewers (SRS and CVB) for eligible studies.

Studies were selected according to the following inclusion criteria: (1) all patients were adults with a clinical diagnosis of PD or clinically uncertain parkinsonism and (2) the study reported original data. In addition, studies needed to fulfill one of the two following criteria: (1) patients underwent at least one DAT SPECT during their life and had postmortem neuropathological evaluation or (2) patients underwent at least two DAT SPECT scans, performed at least 2 years apart. We anticipated that there were only a few studies with DAT SPECT imaging and neuropathological evaluation as reference test (gold standard) available. Therefore, we also included studies that used a second DAT SPECT scan.

The interval of 2 years was chosen to make sure the second DAT SPECT scan would detect any nigrostriatal cell loss. With an annual decline of 5.5 to $7.1 \%$ of dopaminergic neurons in PD and even more in atypical parkinsonian syndromes, a scan at least 2 years later would show a marked decline if nigrostriatal cell loss was present but not visible on the baseline scan $[23,39]$.

All study designs were included with the exception of case reports, case series (less than five patients), and case-control studies. We did not impose restrictions regarding the type of radiotracer used (e.g., $\left[{ }^{123} \mathrm{I}\right] \mathrm{FP}-\mathrm{CIT}$ or $\left[{ }^{123} \mathrm{I}\right] \beta$-CIT). If investigators published several reports based on data from a single study population, we selected the most complete report. Articles were excluded if information on diagnostic accuracy (e.g., sensitivity 
and specificity) could not be derived from the data and could not be obtained from the authors. In all cases, disagreements about study selection were resolved by consensus and a third reviewer (JB) was consulted if disagreement persisted.

\section{Data extraction and risk of bias}

Data were extracted by the two reviewers (SRS and CVB) independently using an extraction form designed for this review. We extracted data on the diagnostic accuracy of the studies, the baseline characteristics of studied patients (e.g., disease duration, age at imaging, Hoehn and Yahr score, and Unified Parkinson's Disease Rating Scale score). We also extracted data on the SPECT technique, which radiotracer was used, handling of DAT interfering medication, patient preparation, test interpretation, technical failures, and assessors (e.g., knowledge of other test results). Results were compared, and discrepancies between the two reviewers were resolved in a meeting.

The Quality Assessment of Diagnostic Accuracy Studies 2 (QUADAS 2) checklist was used to assess the methodological quality of the included studies. The QUADAS 2 tool is structured in a series of questions which should be answered 'yes', 'no', or 'unclear' and aims to evaluate the risk of different types of bias [40].

\section{Statistical analysis and data synthesis}

For each study, patient and study characteristics were summarized using descriptive statistics. Diagnostic accuracy was described in terms of sensitivity and specificity rates with their $95 \%$ confidence intervals (CI). We did not perform a meta-analysis because we included a heterogeneous group of patients with a clinical diagnosis of PD as well as with clinically uncertain parkinsonism in this review. This alters the spectrum of disease and non-disease in the population, which may have strong impact on test accuracy.

\section{Results}

\section{Literature search and study selection}

Figure 1 shows the results of the Additional file 1 search and the study selection. We identified 2,239 articles. After duplicate removal, 1,649 articles remained. A total of 1,632 articles were excluded because they did not fulfill our selection criteria. The large majority of these studies were excluded because they did not employ multiple DAT SPECT scans or neuropathological evaluation.

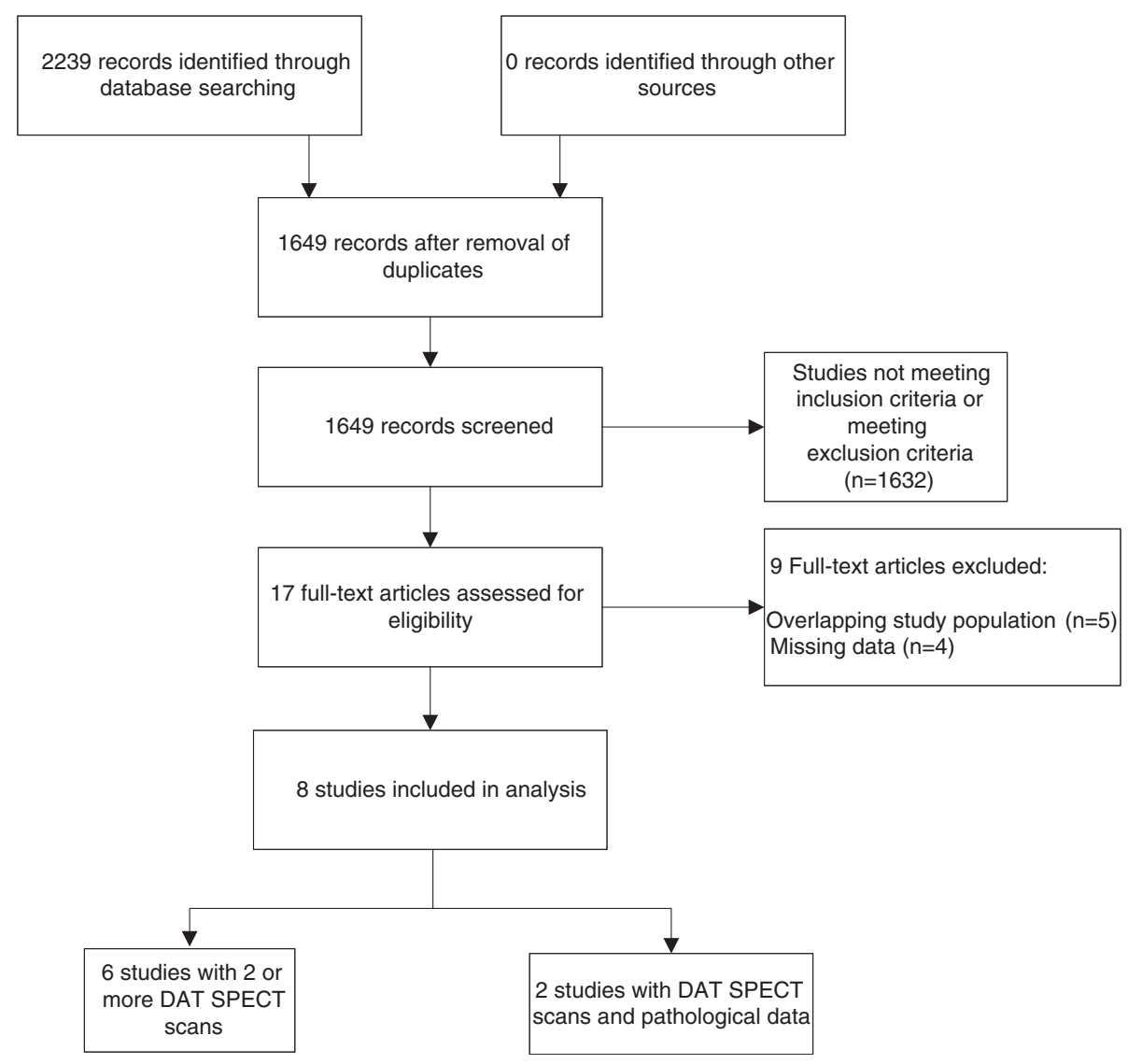

Figure 1 Flowchart of eligible studies. 


\section{Table 1 Patient and study characteristics}

\begin{tabular}{|c|c|c|c|c|c|c|c|c|c|c|c|c|c|c|}
\hline $\begin{array}{l}\text { Author, } \\
\text { year }\end{array}$ & $\begin{array}{l}\text { Number of } \\
\text { patients }\end{array}$ & $\begin{array}{l}\text { Target } \\
\text { population }\end{array}$ & $\begin{array}{l}\text { Inclusion } \\
\text { criteria }\end{array}$ & $\begin{array}{l}\text { Prospective or } \\
\text { retrospective? }\end{array}$ & $\begin{array}{l}\text { Reference } \\
\text { standard }\end{array}$ & $\begin{array}{l}\text { Mean disease } \\
\text { duration at } \\
\text { 1st scan } \\
(y \pm S D)\end{array}$ & $\begin{array}{l}\text { Mean } \\
\text { age at } \\
\text { imaging } \\
(y \pm S D)\end{array}$ & $\begin{array}{l}\text { Mean } \\
\text { Hoehn } \\
\text { and Yahr } \\
\text { score }\end{array}$ & $\begin{array}{l}\text { Mean UPDRS } \\
\text { motor score } \\
\text { at imaging } \\
\text { (OFF state, } \\
0 \text { to 108) }\end{array}$ & $\begin{array}{l}\text { Mean follow- } \\
\text { up between } \\
\text { scans } \\
(y+S D)\end{array}$ & Radiotracer & $\begin{array}{l}\text { SPECT judged } \\
\text { visually, } \\
\text { template or } \\
\text { drawn }\end{array}$ & $\begin{array}{l}\text { Drug } \\
\text { stopped } \\
\text { appropriate } \\
\text { before SPECT? }\end{array}$ & $\begin{array}{l}\text { SPECT judged } \\
\text { blindly for } \\
\text { results of } \\
\text { reference } \\
\text { standard? }\end{array}$ \\
\hline $\begin{array}{l}\text { Chouker, } \\
2001 \text { [20] }\end{array}$ & 8 & Clinical PD & $\begin{array}{l}\text { Step } 1+2 \\
\text { UKPDS criteria + } \\
\text { response to } \\
\text { dopaminomimetics }\end{array}$ & Prospective & $\begin{array}{l}\text { 2nd DAT } \\
\text { SPECT }\end{array}$ & $3.6^{*}, 1$ to $6^{*}$ & $\begin{array}{l}57.0,40 \text { to } \\
76^{*}\end{array}$ & $2.0 \pm 0.8$ & - & 2.0 & IPT & Template & Unclear & Unclear \\
\hline $\begin{array}{l}\text { Marek, } \\
2001 \text { [22] }\end{array}$ & 32 & Clinical PD & $\begin{array}{l}\text { Step } 1+2 \\
\text { UKPDS criteria }\end{array}$ & Prospective & $\begin{array}{l}\text { 2nd DAT } \\
\text { SPECT }\end{array}$ & $2.5^{*} \pm 2.4$ & $60.0 \pm 11.7$ & $1.8 \pm 0.7$ & $18.2 \pm 8.7$ & $2.3 \pm 0.9$ & Beta & Drawn & Unclear & Yes \\
\hline $\begin{array}{l}\text { Pirker, } \\
2002 \text { [23] }\end{array}$ & 36 & Clinical PD & $\begin{array}{l}\text { Step } 1+2 \\
\text { UKPDS criteria }\end{array}$ & Prospective & $\begin{array}{l}\text { 2nd DAT } \\
\text { SPECT }\end{array}$ & $4.7^{*} \pm 2.9$ & $60.0 \pm 11.0$ & $2.1 \pm 0.4$ & & $2.2 \pm 0.3$ & Beta & Drawn & Yes & Yes \\
\hline $\begin{array}{l}\text { Marshall, } \\
2009 \text { [49] }\end{array}$ & 99 & $\begin{array}{l}\text { Clinically } \\
\text { uncertain } \\
\text { parkinsonism }\end{array}$ & $\begin{array}{l}\text { Step } 1 \\
\text { UKPDS criteria }\end{array}$ & Prospective & $\begin{array}{l}\text { 2nd DAT } \\
\text { SPECT }\end{array}$ & $2.4^{\neq}$ & $60.8 \pm 4.8$ & $1.5 \pm 0.3$ & $9.6 \pm 1.3$ & 3.0 & fpcit & Visual & Yes & Yes \\
\hline $\begin{array}{l}\text { Isaias, } \\
2010 \text { [48] }\end{array}$ & 13 & Clinical PD & $\begin{array}{l}\text { Steps } 1 \text { to } 3 \\
\text { UKPDS criteria }\end{array}$ & Prospective & $\begin{array}{l}\text { 2nd DAT } \\
\text { SPECT }\end{array}$ & $5.0^{*} \pm 2.8$ & $63.4 \pm 8.5$ & & $17.2 \pm 6.0$ & $3.2 \pm 1.0$ & fpcit & Template & Yes & Unclear \\
\hline $\begin{array}{l}\text { Perju- } \\
\text { Dumbrava, } \\
2012 \text { [46] }\end{array}$ & 8 & $\begin{array}{l}\text { Pathologically } \\
\text { proven PD }\end{array}$ & $\begin{array}{l}\text { Neuropathological } \\
\text { diagnosis of PD + } \\
\text { DAT scan during } \\
\text { lifetime }\end{array}$ & Retrospective & $\begin{array}{l}\text { Pathological } \\
\text { evaluation }\end{array}$ & $4.1^{*} \pm 4.8$ & $68.0 \pm 7.2$ & - & - & $3.7 \pm 3.0^{d}$ & Beta & Drawn & Unclear & Unclear \\
\hline $\begin{array}{l}\text { Colloby, } \\
2012 \text { [47] }\end{array}$ & 12 & $\begin{array}{l}\text { Pathologically } \\
\text { proven PDD }\end{array}$ & $\begin{array}{l}\text { PDD according to } \\
\text { McKeith criteria + } \\
\text { DAT scan during } \\
\text { lifetime }\end{array}$ & Retrospective & $\begin{array}{l}\text { Pathological } \\
\text { evaluation }\end{array}$ & $7.9^{*} \pm 6.3$ & $70.8 \pm 4.3$ & & $35.8 \pm 11.9$ & $3.3 \pm 1.7^{q}$ & fpcit & Template & Unclear & Unclear \\
\hline $\begin{array}{l}\text { Eggers, } \\
2012 \text { [45] }\end{array}$ & 27 & Clinical PD & $\begin{array}{l}\text { Steps } 1 \text { to } 3 \\
\text { UKPDS criteria }\end{array}$ & Retrospective & $\begin{array}{l}\text { 2nd DAT } \\
\text { SPECT }\end{array}$ & $3.9^{*}$ & $61.7 \pm 11.2$ & - & $25.9 \pm 5.2$ & $2.5 \pm 0.7$ & fpcit & Template & Yes & Yes \\
\hline
\end{tabular}

PD, Parkinson's Disease; SD, standard deviation; UPDRS, Unified Parkinson's disease rating scale; beta, $\left.\left.{ }^{123}\right]\right]$-carboxymethyoxy-3-beta-(4-iodophenyl) tropane; fpcit, [23 $]$-fluoropropyl-carbomethoxy-3 $\beta$-4-iodophenyltropane; IPT, ${ }^{123}$-N-(3-iodopropen-2-yl)-2-carbomethoxy-33-(4-chlorophenyl) tropane; SPECT, single-photon emission computed tomography; Cl, confidence interval; PDD, Parkinson's disease dementia; DAT, dopamine transporter; UKPDS, United Kingdom Parkinson's Disease society.

*Full range instead of standard deviation.

*Disease duration calculated from diagnosis.

IIn this study, the interval is referring to the time between DAT SPECT imaging and pathological evaluation. 
Seventeen articles were selected for further review. Of these, five were excluded because the study population overlapped with more complete or more recent publications. We contacted the authors of five additional studies that had missing data [41-44]. One author responded [23]. The other four articles were excluded. In the end, eight studies fulfilled our selection criteria.

\section{Study characteristics}

The characteristics of the included studies are shown in Table 1. The eight included studies involved a total of 235 patients. There was only one study that assessed patients with clinically uncertain parkinsonism [45], all other studies included patients with a clinical diagnosis of PD (five studies) or pathologically proven PD (two studies). The mean disease duration at first SPECT imaging ranged from 2.4 to 7.9 years.

Two studies used pathological evaluation as the reference standard $[46,47]$. The other six studies used a second DAT SPECT scan, at least 2 years later, as surrogate reference standard $[20,22,23,45,48,49]$. The studies using pathological evaluation were retrospective studies. All but one of the studies that used a second DAT SPECT scan was prospective studies.

\section{Risk of bias}

The risk of bias in the included studies is shown in Table 2. Most studies had at least one design flaw. Five out of the eight studies had an unclear or a high risk of bias regarding patient selection due to a poor description of patient recruitment. In three out of eight studies, there was a concern regarding patient flow. There was a selection of patients that received the reference standard (second DAT SPECT or pathological evaluation). In two studies, we found previous reports with more patients than the ones selected. However, the reasons for exclusion of the extra patients were not mentioned in the manuscript. In four of the eight studies, it was unclear if the assessor of the index test was blinded for the results of the reference test and/or clinical diagnosis.

\section{Diagnostic accuracy}

Only in the study of patients with clinically uncertain parkinsonism, a high diagnostic accuracy of DAT SPECT imaging was observed with sensitivity and specificity rates of $98 \%$. Only in two out of 99 patients, DAT SPECT results at follow-up differed compared to the initial DAT SPECT scan [49]. In the other seven studies that included patients with a clinical or neuropathological diagnosis of PD - DAT SPECT imaging had sensitivity rates of $100 \%$. In six of these seven studies, specificity rates could not be calculated as the reference tests indicated all patients had nigrostriatal cell loss. In the study of Marek and colleagues, 30 patients showed nigrostriatal cell loss at imaging and two did not. Sensitivity and specificity rates were both $100 \%$. An important finding of all seven studies is that the results did not change in the course of 2.0 to 3.7 years.

\section{Discussion}

Our study indicates that DAT SPECT imaging may be accurate in detecting the loss of nigrostriatal dopaminergic cells. As anticipated, there are only two studies having both DAT SPECT imaging and pathological evaluation. None of these studies performed DAT SPECT imaging in early-stage clinical PD or in patients with clinically uncertain parkinsonism. However, these two studies show that DAT SPECT imaging at medium-long disease duration (4.1 to 7.9 years) is able to detect nigrostriatal cell loss $[46,47]$.

A limitation of this review is that the majority of included studies performed serial DAT SPECT imaging in patients with a high suspicion of PD. These studies were designed to measure disease progression. In one of the

Table 2 Risk of bias as assessed with the Quadas-2 tool

\begin{tabular}{|c|c|c|c|c|c|c|c|}
\hline \multirow[t]{2}{*}{ Study } & \multicolumn{4}{|c|}{ Risk of bias } & \multicolumn{3}{|c|}{ Applicability concerns } \\
\hline & $\begin{array}{l}\text { Patient } \\
\text { selection }\end{array}$ & $\begin{array}{l}\text { Index } \\
\text { test }\end{array}$ & $\begin{array}{l}\text { Reference } \\
\text { standard }\end{array}$ & $\begin{array}{l}\text { Flow and } \\
\text { timing }\end{array}$ & $\begin{array}{l}\text { Patient } \\
\text { selection }\end{array}$ & $\begin{array}{l}\text { Index } \\
\text { test }\end{array}$ & $\begin{array}{l}\text { Reference } \\
\text { standard }\end{array}$ \\
\hline Chouker, [20] & + & $?$ & $?$ & + & + & + & + \\
\hline Marek, [22] & $?$ & + & + & - & + & + & + \\
\hline Pirker, [23] & + & + & + & + & + & + & + \\
\hline Marshall, [49] & + & + & + & + & + & + & + \\
\hline Isaias, [48] & $?$ & $?$ & $?$ & - & + & + & + \\
\hline Perju-Dumbrava, [46] & - & $?$ & $?$ & + & + & + & + \\
\hline Colloby, [47] & - & $?$ & $?$ & + & + & + & + \\
\hline Eggers, [50] & - & + & + & - & + & + & + \\
\hline
\end{tabular}

+Low risk, -High risk, ?Unclear Risk. 
studies, two patients had a negative reference standard. In the other studies, all included patients had a positive reference standard and consequently specificity rates of the index test could not be calculated. However, these results are inline with the only study that evaluated the diagnostic accuracy in patients with clinically uncertain parkinsonism (sensitivity and specificity $98 \%$ ).

Another limitation is that in four studies it is not clear whether the investigators assessing the SPECT images were blinded for signs and symptoms or for the reference standard.

Other (systematic) reviews on the accuracy of DAT SPECT imaging showed somewhat lower sensitivity (79 to $100 \%$ ) and specificity (80 to $100 \%$ ) $[18,50,51]$. These reviews used the clinical diagnosis at follow-up as reference standard. The clinical diagnosis is accurate in 65 to $94 \%$ of the patients compared to the final pathological diagnosis [4,9-11]. The accuracy of the clinical diagnosis increases with the duration of symptoms $[49,52]$. However, most studies and clinical trials use the clinical diagnosis 3 to 36 months after the initial diagnosis as reference standard [53-56]. This inaccurate reference standard might explain that the accuracy of DAT SPECT imaging is somewhat lower in these studies.

Therefore, there is a need for an alternative in vivo reference standard to detect nigrostriatal dopaminergic cell loss in patients with parkinsonism. To evaluate new screening methods, and ultimately the accuracy of the clinical criteria for (early) PD, a reliable and practical reference standard to detect nigrostriatal cell loss is needed [57-60]. The current reference standard (gold standard), pathological evaluation, is accurate, however, not very practical to use to evaluate the accuracy of the clinical criteria because the time between the clinical diagnosis and pathological diagnosis is typically long.

For clinical trials, it will be better and more practical to have an accurate in vivo reference standard to ensure no patients with other diagnoses are included. If diseasemodifying therapies become available, it will also be desirable to identify patients as early as possible, maybe even in a premotor phase $[61,62]$. Especially considering that using the clinical criteria, based on motor symptoms, more than $50 \%$ of the dopamine producing neurons are lost $[61,62]$.

\section{Conclusions}

It seems that DAT SPECT imaging could be used as an in vivo reference standard to detect nigrostriatal cell loss and evaluate new diagnostic (screening) methods. However, considering only one study included patients with diagnostic uncertainty more diagnostic accuracy studies are needed to confirm this finding.

\section{Additional file}

\section{Additional file 1: MEDLINE and EMBASE search strategies.}

\section{Competing interests}

JB is a consultant at GE Healthcare. The other authors declare that they have no competing interests.

\section{Authors' contributions}

$\mathrm{RdB}, \mathrm{SRS}, \mathrm{JB}$, and $\mathrm{JdH}$ conceived of the review and participated in its design and coordination and helped to draft the manuscript. The list of titles and abstracts were screened by two independent reviewers (SRS and CVB). Data extraction and quality assessment was done by SRS and CVB. All authors read and approved the final manuscript.

\section{Author details}

${ }^{1}$ Department of Neurology, Academic Medical Center, University of Amsterdam, Meibergdreef 9, PO Box 22660, 1100 DD Amsterdam, The Netherlands. ${ }^{2}$ Department of Neurology, Medical Center Haaglanden, Lijnbaan 32, PO Box 432, 2501 CK The Hague, The Netherlands. ${ }^{3}$ Department of Clinical Research Unit, Academic Medical Center, University of Amsterdam, Meibergdreef 9, PO Box 22660, 1100 DD Amsterdam, The Netherlands. ${ }^{4}$ Department of Neurology, Atrium Medical Center Parkstad, Henri Dunantstraat 5, PO Box 4446, 6401 CX Heerlen, The Netherlands.

${ }^{5}$ Department of Nuclear Medicine, Academic Medical Center, University of Amsterdam, Meibergdreef 9, PO Box 22660, 1100 DD Amsterdam, The Netherlands.

Received: 14 January 2015 Accepted: 19 February 2015

Published online: 17 March 2015

\section{References}

1. de Rijk MC, Tzourio C, Breteler MM, Dartigues JF, Amaducci L, Lopez-Pouza S, et al. Prevalence of parkinsonism and Parkinson's disease in Europe: the EUROPARKINSON Collaborative Study. European Community Concerted Action on the Epidemiology of Parkinson's disease. J Neurol Neurosurg Psychiatry. 1997;62:10-5.

2. de Lau LM, Breteler MM. Epidemiology of Parkinson's disease. Lancet Neurol. 2006;5:525-35.

3. Hughes AJ, Daniel SE, Kilford L, Lees AJ. Accuracy of clinical diagnosis of idiopathic Parkinson's disease: a clinico-pathological study of 100 cases. J Neurol Neurosurg Psychiatry. 1992;55:181-4.

4. Hughes AJ, Daniel SE, Lees AJ. Improved accuracy of clinical diagnosis of Lewy body Parkinson's disease. Neurology. 2001;57:1497-9.

5. Jankovic J. Diagnosis and treatment of psychogenic parkinsonism. J Neurol Neurosurg Psychiatry. 2011;82:1300-3.

6. Shin DH, Lee PH, Bang OY, Joo IS, Huh K. Clinical implications of cardiac-MIBG SPECT in the differentiation of Parkinsonian Syndromes. J Clin Neurol. 2006:2:51-7.

7. Jankovic J, Rajput AH, McDermott MP, Perl DP. The evolution of diagnosis in early Parkinson disease. Parkinson Study Group Arch Neurol. 2000;57:369-72.

8. Tolosa E, Wenning G, Poewe W. The diagnosis of Parkinson's disease. Lancet Neurol. 2006;5:75-86.

9. Ravina B, Marek K, Eberly S, Oakes D, Kurlan R, Ascherio A, et al. Dopamine transporter imaging is associated with long-term outcomes in Parkinson's disease. Mov Disord. 2012;27:1392-7.

10. Litvan I, MacIntyre A, Goetz CG, Wenning GK, Jellinger K, Verny M, et al. Accuracy of the clinical diagnoses of Lewy body disease, Parkinson disease, and dementia with Lewy bodies: a clinicopathologic study. Arch Neurol. 1998;55:969-78.

11. Hughes AJ, Daniel SE, Ben-Shlomo Y, Lees AJ. The accuracy of diagnosis of parkinsonian syndromes in a specialist movement disorder service. Brain. 2002;125:861-70.

12. Meara J, Bhowmick BK, Hobson P. Accuracy of diagnosis in patients with presumed Parkinson's disease. Age Ageing. 1999;28:99-102

13. Mian OS, Schneider SA, Schwingenschuh P, Bhatia KP, Day BL. Gait in SWEDDs patients: comparison with Parkinson's disease patients and healthy controls. Mov Disord. 2011;26:1266-73. 
14. Kim JS, Oh YS, Kim YI, Yang DW, Chung YA, You IR, et al. Combined use of [123I]-metaiodobenzylguanidine (MIBG) scintigraphy and dopamine transporter (DAT) positron emission tomography (PET) predicts prognosis in drug-induced Parkinsonism (DIP): a 2-year follow-up study. Arch Gerontol Geriatr. 2012;56:124-8.

15. Whone AL, Watts RL, Stoessl AJ, Davis M, Reske S, Nahmias C, et al. Slower progression of Parkinson's disease with ropinirole versus levodopa: the REAL-PET study. Ann Neurol. 2003;54:93-101.

16. Morrish PK, Sawle GV, Brooks DJ. Clinical and [18 F] dopa PET findings in early Parkinson's disease. J Neurol Neurosurg Psychiatry. 1995;59:597-600.

17. De la Fuente-Fernandez R. Role of DaTSCAN and clinical diagnosis in Parkinson disease. Neurology. 2012;78:696-701.

18. Vlaar AM, van Kroonenburgh MJ, Kessels AG, Weber WE. Meta-analysis of the literature on diagnostic accuracy of SPECT in parkinsonian syndromes. BMC Neurol. 2007;7:27

19. Benamer TS, Patterson J, Grosset DG, Booij J, de Bruin K, van Royen E. Accurate differentiation of parkinsonism and essential tremor using visual assessment of [123I]-FP-CIT SPECT imaging: the [123I]-FP-CIT study group. Mov Disord. 2000;15:503-10.

20. Chouker M, Tatsch K, Linke R, Pogarell O, Hahn K, Schwarz J. Striatal dopamine transporter binding in early to moderately advanced Parkinson's disease: monitoring of disease progression over 2 years. Nucl Med Commun. 2001;22:721-5

21. Fahn S, Oakes D, Shoulson I, Kieburtz K, Rudolph A, Lang A, et al. Levodopa and the progression of Parkinson's disease. N Engl J Med. 2004;351:2498-508.

22. Marek K, Innis R, van Dyck C, Fussell B, Early M, Eberly S, et al. [123l]beta-CIT SPECT imaging assessment of the rate of Parkinson's disease progression. Neurology. 2001;57:2089-94.

23. Pirker W, Djamshidian S, Asenbaum S, Gerschlager W, Tribl G, Hoffmann M, et al. Progression of dopaminergic degeneration in Parkinson's disease and atypical parkinsonism: a longitudinal beta-CIT SPECT study. Mov Disord. 2002;17:45-53

24. Staffen W, Mair A, Unterrainer J, Trinka E, Ladurner G. Measuring the progression of idiopathic Parkinson's disease with [123I] beta-CIT SPECT. J Neural Transm. 2000;107:543-52.

25. Berendse HW, Booij J, Francot CM, Bergmans PL, Hijman R, Stoof JC, et al. Subclinical dopaminergic dysfunction in asymptomatic Parkinson's disease patients' relatives with a decreased sense of smell. Ann Neurol. 2001;50:34-41.

26. Iranzo A, Lomena F, Stockner H, Valldeoriola F, Vilaseca I, Salamero M, et al. Decreased striatal dopamine transporter uptake and substantia nigra hyperechogenicity as risk markers of synucleinopathy in patients with idiopathic rapid-eye-movement sleep behaviour disorder: a prospective study [corrected]. Lancet Neurol. 2010;9:1070-7.

27. Sommer U, Hummel T, Cormann K, Mueller A, Frasnelli J, Kropp J, et al. Detection of presymptomatic Parkinson's disease: combining smell tests, transcranial sonography, and SPECT. Mov Disord. 2004;19:1196-202.

28. Stiasny-Kolster K, Doerr Y, Moller JC, Hoffken H, Behr TM, Oertel WH, et al. Combination of 'idiopathic' REM sleep behaviour disorder and olfactory dysfunction as possible indicator for alpha-synucleinopathy demonstrated by dopamine transporter FP-CIT-SPECT. Brain. 2005;128:126-37.

29. Cilia R, Rossi C, Frosini D, Volterrani D, Siri C, Pagni C, et al. Dopamine transporter SPECT imaging in Corticobasal Syndrome. PLoS One. 2011:6:e18301.

30. Scherfler C, Schwarz J, Antonini A, Grosset D, Valldeoriola F, Marek K, et al. Role of DAT-SPECT in the diagnostic work up of parkinsonism. Mov Disord. 2007:22:1229-38

31. Vlaar AM, de Nijs T, Kessels AG, Vreeling FW, Winogrodzka A, Mess WH, et al. Diagnostic value of [123I]-ioflupane and [123I]-iodobenzamide SPECT scans in 248 patients with parkinsonian syndromes. Eur Neurol. 2008:59:258-66.

32. Becker G, Seufert J, Bogdahn U, Reichmann H, Reiners K. Degeneration of substantia nigra in chronic Parkinson's disease visualized by transcranial color-coded real-time sonography. Neurology. 1995;45:182-4.

33. Berg D, Godau J, Walter U. Transcranial sonography in movement disorders. Lancet Neurol. 2008;7:1044-55.

34. Stockner $H$, Schwingenschuh $P$, Djamshidian A, Silveira-Moriyama L, Katschnig P, Seppi K, et al. Is transcranial sonography useful to distinguish scans without evidence of dopaminergic deficit patients from Parkinson's disease? Mov Disord. 2012;27:1182-5.
35. Gaenslen A, Unmuth B, Godau J, Liepelt I, Di Santo A, Schweitzer KJ, et al. The specificity and sensitivity of transcranial ultrasound in the differential diagnosis of Parkinson's disease: a prospective blinded study. Lancet Neurol. 2008;7:417-24.

36. Izawa MO, Miwa H, Kajimoto Y, Kondo T. Combination of transcranial sonography, olfactory testing, and MIBG myocardial scintigraphy as a diagnostic indicator for Parkinson's disease. Eur J Neurol. 2012;19:411-6.

37. Vlaar AM, Bouwmans A, Mess WH, Tromp SC, Weber WE. Transcranial duplex in the differential diagnosis of parkinsonian syndromes: a systematic review. J Neurol. 2009:256:530-8.

38. Stockner H, Sojer M, Seppi KK, Mueller J, Wenning GK, Schmidauer C, et al. Midbrain sonography in patients with essential tremor. Mov Disord. 2007:22:414-7.

39. Morrish PK, Rakshi JS, Bailey DL, Sawle GV, Brooks DJ. Measuring the rate of progression and estimating the preclinical period of Parkinson's disease with [18 F]dopa PET. J Neurol Neurosurg Psychiatry. 1998;64:314-9.

40. Whiting PF, Rutjes AW, Westwood ME, Mallet S, Deeks JJ, Reitsma JB, et al. QUADAS-2: a revised tool for the quality assessment of diagnostic accuracy studies. Ann Intern Med. 2011;155:529-36.

41. Catafau AM, Vander BT TE, DaTSCAN Clinically Uncertain Parkinsonian Syndromes Study Group. Impact of dopamine transporter SPECT using 1231-loflupane on diagnosis and management of patients with clinically uncertain parkinsonian syndromes. Mov Disord. 2004;19:1175-82.

42. Parkinson Study Group. Dopamine transporter brain imaging to assess the effects of pramipexole vs levodopa on Parkinson disease progression. JAMA. 2002;287:1653-61.

43. Parkinson Study Group. Mixed lineage kinase inhibitor CEP-1347 fails to delay disability in early Parkinson disease. Neurology. 2007;69:1480-90.

44. Bender A, Koch W, Elstner M, Schombacher Y, Bender J, Moeschl M, et al. Creatine supplementation in Parkinson disease: a placebo-controlled randomized pilot trial. Neurology. 2006;67:1262-4.

45. Eggers C, Pedrosa DJ, Kahraman D, Maier F, Lewis CJ, Fink GR, et al. Parkinson subtypes progress differently in clinical course and imaging pattern. PLoS One. 2012;7:e46813.

46. Perju-Dumbrava LD, Kovacs GG, Pirker S, Jellinger K, Hoffmann M, Asenbaum S, et al. Dopamine transporter imaging in autopsy-confirmed Parkinson's disease and multiple system atrophy. Mov Disord. 2012;27:65-71

47. Colloby SJ, McParland S, O'Brien JT, Attems J. Neuropathological correlates of dopaminergic imaging in Alzheimer's disease and Lewy body dementias. Brain. 2012;135:2798-808.

48. Isaias IU, Marotta G, Hirano S, Canesi M, Benti R, Righini A, et al. Imaging essential tremor. Mov Disord. 2010;25:679-86.

49. Marshall VL, Reininger CB, Marquardt M, Patterson J, Hadley DM, Oertel WH, et al. Parkinson's disease is overdiagnosed clinically at baseline in diagnostically uncertain cases: a 3-year European multicenter study with repeat $\left[{ }^{123}\right.$ I] FP-CIT SPECT. Mov Disord. 2009;24:500-8.

50. Bajaj N, Hauser RA, Grachev ID. Clinical utility of dopamine transporter single photon emission CT (DaT-SPECT) with [123I] ioflupane in diagnosis of parkinsonian syndromes. J Neurol Neurosurg Psychiatry. 2013;84:1288-95.

51. Kagi G, Bhatia KP, Tolosa E. The role of DAT-SPECT in movement disorders. J Neurol Neurosurg Psychiatry. 2010;81:5-12.

52. Bajaj NP, Gontu V, Birchall J, Patterson J, Grosset DG, Lees AJ. Accuracy of clinical diagnosis in tremulous parkinsonian patients: a blinded video study. J Neurol Neurosurg Psychiatry. 2010;81:1223-8.

53. Tolosa E, Borght TV, Moreno E. Accuracy of DaTSCAN ([123I]-loflupane) SPECT in diagnosis of patients with clinically uncertain parkinsonism: 2-year follow-up of an open-label study. Mov Disord. 2007;22:2346-51.

54. Ziebell M, Andersen BB, Thomsen G, Pinborg LH, Karlsborg M, Hasselbach SG, et al. Predictive value of dopamine transporter SPECT imaging with [123l]PE2I in patients with subtle parkinsonian symptoms. Eur J Nucl Med Mol Imaging. 2012;39:242-50.

55. Jennings D, Siderowf A, Stern M, Seibyl J, Eberly S, Oakes D, et al. Imaging prodromal Parkinson disease. Neurology. 2014;83:1739-46.

56. Bajaj N, Hauser RA, Seibyl J, Kupsch A, Plotkin M, Chen C, et al. Association between Hoehn and Yahr, Mini-Mental State Examination, age, and clinical syndrome predominance and diagnostic effectiveness of ioflupane I 123 injection (DaTSCAN ${ }^{\mathrm{TM}}$ ) in subjects with clinically uncertain parkinsonian syndromes. Alzheimer's ResTherapy. 2014;6:67.

57. Stephenson R, Siderowf A, Stern MB. Premotor Parkinson's disease: clinical features and detection strategies. Mov Disord. 2009;24:S665-70. 
58. Lang AE. A critical appraisal of the premotor symptoms of Parkinson's disease: potential usefulness in early diagnosis and design of neuroprotective trials. Mov Disord. 2011;26:775-83.

59. Siderowf A, Lang AE. Premotor Parkinson's disease: concepts and definitions. Mov Disord. 2012;27:608-16.

60. Mahlknecht P, Poewe W. Is there a need to redefine Parkinson's disease? J Neural Transm. 2013;9:S9-17.

61. Langston JW. Predicting Parkinson's disease. Neurology. 1990;40:S4.

62. Hornykiewicz O, Kish SJ. Biochemical pathophysiology of Parkinson's disease. Adv Neurol. 1987:45:19-34.

Submit your manuscript to a SpringerOpen ${ }^{\circ}$ journal and benefit from:

- Convenient online submission

- Rigorous peer review

- Immediate publication on acceptance

- Open access: articles freely available online

- High visibility within the field

- Retaining the copyright to your article

Submit your next manuscript at springeropen.com 